CENDEKIA, Vol. 12, No. 1, April 2018

p ISSN: 1978 2098; e ISSN: 2407 8557

Http://cendekia.pusatbahasa.or.id; Email: cendekiaoslo@gmail.com

Center of Language and Culture Studies, Surakarta, Indonesia

Hamid, Munir Ahmad. 2018. Islamic Governance in Islamic School Finance.

Cendekia, (2018), 12(1): 1 22. DOI: 10.30957/cendekia.v12i.433.

\title{
ISLAMIC GOVERNANCE IN ISLAMIC SCHOOL FINANCE
}

\author{
Ahmad Munir Hamid \\ Postgraduate School of Airlangga University \\ Email:hamtik1@gmail.com
}

\begin{abstract}
The purpose of this study is to analyze the concept of Islamic finance governance which includes the principles among others; tauhid, taqwa and ridho, equilibrium (balance and justice), benefit, transparency, responsibility (responsibility) and independence. This research uses descriptive qualitative method using literature approach (literature), either in the form of books, notes, or research result report, from previous researcher. The literature used in this research is books, journals, theses, and articles related to Good Corporate Governance in Islamic perspective and its application to sharia banking in the world.Islam has a much more complete and more comprehensive concept and akhlaqulkarimah and ketaqwaan to Allah SWT is a solid wall not to get mired in illegal practices and dishonest in accepting the mandate. Principles of Islamic Governance (IG) after going through the process of analysis and data processing there are nine interrelated principles, the principles are derived kalamullah and rasulullah who can answer from some corruption crime to efforts in improving efficiency, competitiveness and product innovation and sharia banking services.
\end{abstract}

Key words: Islamic governance; Principle; and Islamic Financial Shools.

\section{INTRODUCTION}

Education provider is expected to allocate funding according to need. Besides improving the quality of education needs to be supported by the ability of managerial leadership. Managers should strive to set up financial resources effectively and efficiently in order to support the achievement of educational goals optimally. In the implementation of education activities, management of education funding is potentially a very urgent, is an integral part in the study of management education. Financing component in a school production of components which determine the implementation of educational activities in this learning process. Each educational activity will be executed if the good education finance management. Components of the financing will support the achievement of educational goals.

According to Setiawan (2015) on the official website of the Ministry of Education and Culture (Kemendikbud) from 2011 to 2014 there were 562 complaints about irregularities regulations as well as 113 complaints about the diversion of funds. Of all irregularities and deviations are not all due to intentional factor, but comes also from various misconceptions about management education. The education sector is allocated funds from the government amounting to $20 \%$ of the state budget, or around Rp 368 trillion, which is of course a quality improvement efforts. Most or Rp 268 
CENDEKIA, Vol. 12, No. 1, April 2018

p ISSN: 1978 2098; e ISSN: 2407 8557

Http://cendekia.pusatbahasa.or.id; Email: cendekiaoslo@gmail.com

Center of Language and Culture Studies, Surakarta, Indonesia

Hamid, Munir Ahmad. 2018. Islamic Governance in Islamic School Finance. Cendekia, (2018), 12(1): 1 22. DOI: 10.30957/cendekia.v12i.433.

trillion, is transferred to the region through a variety of allocation, such as the special allocation fund and the general allocation fund.

Irawan (2017) revealed that the educational institution should be a bulwark in the fight against corruption, it actually engage in corrupt practices. Corruption in education involve starting from policy makers to educational institutions such as schools and colleges. Starting from the year 2005 to 2016 there were about 425 cases of corruption. A total of 214 cases of corruption occurred in the education office education (www.tribunnewa.com).

According to Fatah (2000), education affects the economic growth of a nation in improving the quality of Indonesian people, the government is not a loose system with the private sector and society. Relationships are integral in their role to improve the quality of education. Education is expected to print quality human resources. Concretely, the education must be able to prepare skilled workers. Meanwhile, national education is faced with problems such as quality improvement, allocation of opportunities, budget constraints and unfulfilled resources from the community professionally in accordance with the principle of education as a shared responsibility between government, community and parents.

According Assegaf (2004), the Islamic Educational Reality is now arguably has experienced a period of intellectual deadlock. Among the indicators is the lack of effort to reform, and if there is also less rapidly with changes in social, political and scientific and technological progress. Second, the practice of Islamic education is so far still maintain the old heritage and not a lot of creative thinking, innovative and critical of the current issues. Third, Islamic education learning model emphasizes intellectualismverbalistic approach and negate the importance of humanistic educational interaction and communication between teacher-student. Fourth, the orientation of Islamic education focuses on the formation of a servant of God and not balanced with the achievement of a Muslim human character as khalifatu fi al-ardi.

Mulyasa (2007) describes the Islamic educational institutions have responsibilities in realizing the ideals of the intellectual life of the nation and shaping the personality of a virtuous and prepare qualified human resources to be able to compete in the competitive global world. To achieve this by improving the quality of education. Improving the quality of education is not light duty due to cover a wide range of complex issues, regarding planning, funding, as well as the efficiency and effectiveness of the school system. Islam and Science Islam is the only religion that can integrate religion and values in daily life because it takes science and technology both in realizing it. This is because, in carrying out Islamic practice should be coordinated and integrated in space and time reference systems are interconnected. Science is God's laws are used to organize everything in the universe.

Financial governance contained on suspected Islamic educational institutions not yet fully implement the principles of the school's financial pengelolahan especially the principles of transparency, fairness, and efficiency. For example, fees collected from the students paid the same amount at each grade, whereas the needs of each different grade levels. From these descriptions can be drawn a conclusion that the financial governance of the school to function launched various activities related to education. Financial 
governance adequate school will determine the achievement of educational goals. Education with little resources can take place, but the quality education require substantial funding. Therefore, there are several reasons for the importance of financial governance of the school in achieving quality education services, among others; assisting in the management of financial resources of education in creating a proper control mechanisms for financial decision making is transparent, accountable, and effective and fair.

Good corporate governance (GCG), which in modern terminology is called GCG relating to the hadith of Rasulullah SAW narrated by Aisha ra which means "God loves when someone is doing something job well done". Indonesia as a country with a Muslim majority, should understand and know the principles of GCG in the context of Islam. Principles of GCG in the Islamic context is not something new. These principles have been around for hundreds of years ago in the form of Islamic management. But with the development of the western world capitalist principles, the principles are then abandoned by Muslims. Principles of GCG in Islam refers to the Al-Quran and AlHadith that make it unique and different from the concept of GCG in view of the western world.

Principles of GCG in general is transparency, accountability,responsibiltas, independence, fairness and equity. While the principles of GCG in Islam according to Muqorobin (2011) includes monotheism, piety and good pleasure, equilibrium (balance and fairness), and benefit. According to Abu-Tapanjeh (2009), the principles of Corporate Governance (CG) in Islamic perspective is realized through the framework of the implementation of sharia in business, justice and equality for the benefit and oriented to God as owner and sole authority in the world.

$\mathrm{CG}$ is very important in order pengelolahan school or company, this is according to research conducted by Soraya (2016) GCG is a manifestation of morality in Islam. GCG principles in Islam is monotheism, piety and good pleasure, equilibrium, and welfare. Wijaya (2009) found that expensive education does not automatically indicate the quality of higher education, for higher education is determined by the low cost of the financial management of the school. Setyawan (2015) The principle of fairness, transparency, and accountability in budget management simultaneously affect the productivity of the school. Hafeez (2016) The use of audit, accounting and documentary records of all transactions of companies that either have credibility and be a source of internal control and risk management of financial disclosure and reporting is a key element of corporate transparency of the modern era. In Islam in general, there are two points between faith and piety, science and technology can not be separated (dichotomy) but must unite (chotomous) in the life of a Muslim in order to achieve a balance of interests and happiness hereafter, as stated in the Qur'an Surah al -Qasas, 77 as follows:

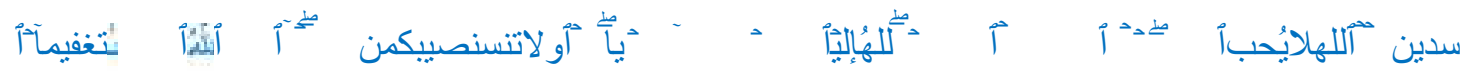


Meaning: And look at what God has given to you (happiness) in the hereafter and do not forget bahagianmu of (enjoyment) world and do good (to others) as Allah has done good to you, and seek not mischief on the (face) of the earth. Allah loves not those who do mischief (Surah Al-Qasas: 77).

This has attracted the attention of researchers to analyze the financial management of the Islamic school which includes planning, and realization of the budget allegedly not been fully carried out based on the principle of school finance governance includes transparency, fairness and efficiency. The use of Islamic principles of governance in the planning and realization of revenue and expenditure budget of the school, in a report obtained funds .. Based on the problems, theories and previous studies described above, the researchers intend to carry out research with the title "ISLAMIC SCHOOL GOVERNANCE IN ISLAMIC FINANCE" ,

\section{METHODS}

The research method used in this research is descriptive qualitative. This method was used for this study aims to provide an explanation of Islamic Governance in increased efficiency and competitiveness, as well as product innovationfourthand services of Islamic banking approach to literature studies obtained from the analysis of international journals and scientific papers from several sources related to GCG, which is widely practiced in commercial banks and Islamic, or also on the company or organization that wants no improvement or productivity also added value in performance.

Creswell (2015:471) describes the qualitative research is interpretive that with the study researchers can make a personal assessment as descriptions that fit the situation or theme that lifted the main categories of information. The interpretation made by researchers to a transcript, for example, differ with the interpretation made by others. This does not mean that the interpretation of the researchers better or more accurate; it simply means that researchers bring perspective to the interpretation.

Data collection techniques used in this study is a library research. Fowler in Sangadji (2010:28) states that the library research is a research carried out by using the literature, either in the form of books, records, and reports the results of the study, from researchers earlier. The literature used in this study are books, journals, theses, and articles related to GCG in Islamic perspective and its application in Islamic business in Indonesia.

\section{RESULTS AND DISCUSSION}

From the analysis of the journals and scientific papers to challenge the practice of CG on financial governance of Islamic schools, many institutions/ schools of Islam that have yet to implement the principles of Islamic governance in the governance of finances, even supposedly still a lot of financial abuse schools (corruption ).

Generally all of these principles are part of the behavior and culture of Muslims, so called the Islamic governance (IG), it shows a positive indicator if done properly and correctly (Sharia compliance). In addition, in an effort to maintain the stability of the new innovations that constructivism is required in order to prevent negative things. 
CENDEKIA, Vol. 12, No. 1, April 2018

p ISSN: 1978 2098; e ISSN: 2407 8557

Http://cendekia.pusatbahasa.or.id; Email: cendekiaoslo@gmail.com

Center of Language and Culture Studies, Surakarta, Indonesia

Hamid, Munir Ahmad. 2018. Islamic Governance in Islamic School Finance.

Cendekia, (2018), 12(1): 1 22. DOI: 10.30957/cendekia.v12i.433.

\section{Literature and Discussion}

CG according to Turbull Report in the UK (April 1999), quoted by TsuguokiFujinuma is as follows:

"CG is a company's system of internal control has as its principal aim the management of risk that are significant to the fulfillment of its business objectives, with a view to safeguarding the company's assets and enchacing over time the value of the shareholders' investment ". (Effendi, 2016:2).

Based on the above understanding, CG is defined as the company's internal control system which has the primary objective to manage significant risks in order to meet its business objectives by securing company's assets and increase the value of shareholders' investment in the long term. According to the World Bank, the notion of GCC is a collection of laws, regulations and rules that must be met, which can push the performance of company resources to function efieien in order to produce economic value of long-term, sustainable for shareholders and the communities as a whole (Effendi, 2016:2).

According to the Forum for Corporate Governance in Indonesia (FCGI), CG is a set of rules that govern the relationship between shareholders, managers, creditors, governments, employees and internal and external stakeholders other with respect to their rights and responsibilities, or a system in which companies are directed and controlled. Based on the Decree of Minister of State 117/M-MBU/2002, CG is a process and structure used by the organs of state-owned enterprises to improve the success of business and corporate accountability in order to create shareholder value in the long term to keep watching stakeholders others, based on legislation and value -value ethics. Organization for Economic Corporation and Development (OECD) in defining GCG is a system used to direct and control the activities of the company.

CG regulates the division of their rights and obligations assignment interested in the life of the company, including shareholders, board members, managers, and all members share nonpemegang stakeholders. Center for European Policy Study (CEPS) to formulate GCG as a whole system formed starting from the right, the process, and the control of either the inside or outside of the company's management (Sutedi, 2011:1). GCG is a Bank's governance which apply the principles of openness (transparency), accountability, liability (responsibility), professional and fairness (fairness) (Bank Indonesia Regulation No. 11/33/PBI/2009). From the various definitions of the above, it can be concluded that GCG is a system that regulate and control the enterprise in order to create added value for the company's stakeholders and surrounding communities (Kay in Sutedi, 2011).

The concept of CG implementation of the principles of GCG arise of developing two interrelated aspects of one with the other, the hardware and software. More technical hardware includes the formation or changes in the structure and organization system. Meanwhile, a more psychosocial software includes a change of paradigm, vision, mission, values, attitude, and behavioral ethics (behavioral ethically). In actual practice in the business world, most companies turned out to be more emphasis on the hardware aspects, such as development of systems and procedures as well as the 
formation of the organizational structure. Implementation of CG in the company as a model system can use the approach of McKinsey in model 1.

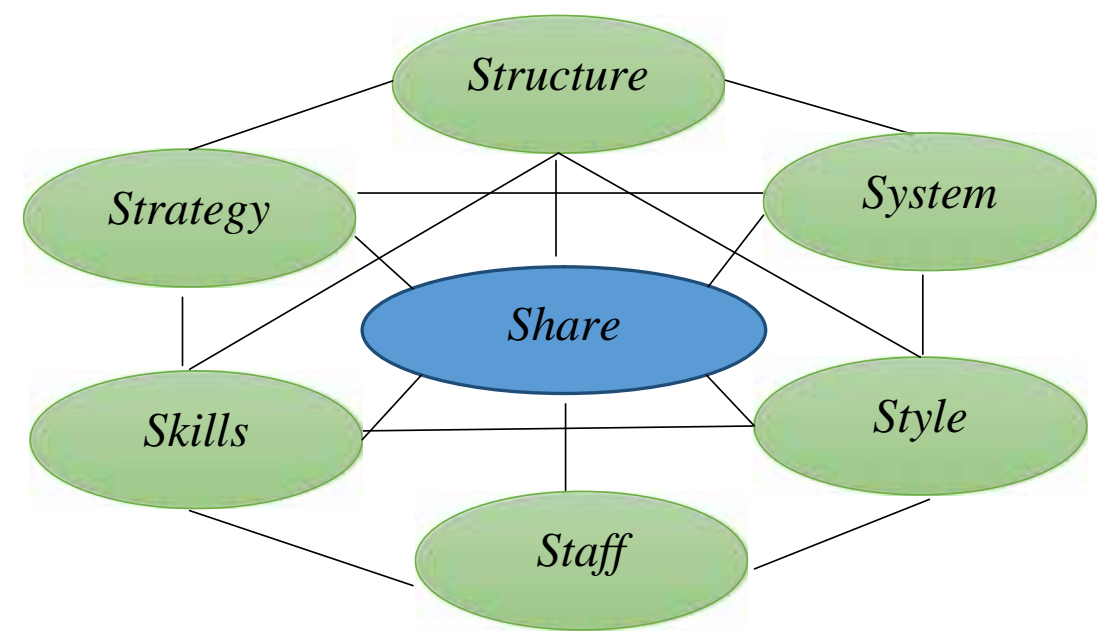

Figure 1 Model 7s of Kinsey

According Efendi (2016: 4), this model consists of two (2) aspects that are the basis or foundation to establish the mechanism of CG as a system, the following descriptions: 1) aspect (hard component) a. Strategy, the organization plans to utilize resourcesto achieve organizational goals. b. Structure, is a way of organizational units relate to each other. c. System, is a step or mechanism taken bymanagementtopand other personal within the organization to achieve organizational goals. 2) Aspects of software (soft component)a. Skill (proficiency), is a special ability of top management and other personal in the organization as a whole to establish the competence of the company. $b$. Style (style of leadership), is the leadership style of top management tosupport the achievement of organizational goals. c. Staff (staff), the ability to cooperate with top management and personal other. d. Shared value, the values held by stakeholders firms that shape the behavior of members of the organization.

Objectives and benefits of GCG in Surya (2006) in Efendi (2016:8), the implementation of GCG in a concrete has a goal against the company as follows: 1) Facilitating access to domestic and foreign investment 2) Getting the cost of capital more Cheap 3) Provide better decisions in improving the economic performance of the company 4) increase the confidence and trust of the stakeholders ofthecompany or organization. 5) Protecting the directors and commissioners of lawsuits. GCG provides a frame of reference that allows effective supervision so as to create a mechanism of checks and balances in the company.

By applying CG at the company, there are some benefits that can be gained (www.fcgi.or.id), namely: 1) reducing agency cost, which is a cost to the shareholder as a result of the delegation of authority to the management. These costs may include losses suffered by the company as a result of abuse of authority (wrong-doing), or in the 
CENDEKIA, Vol. 12, No. 1, April 2018

p ISSN: 1978 2098; e ISSN: 2407 8557

Http://cendekia.pusatbahasa.or.id; Email: cendekiaoslo@gmail.com

Center of Language and Culture Studies, Surakarta, Indonesia

Hamid, Munir Ahmad. 2018. Islamic Governance in Islamic School Finance.

Cendekia, (2018), 12(1): 1 22. DOI: 10.30957/cendekia.v12i.433.

form of supervision costs incurred to prevent it. 2) Reducing the cost of capital (cost of capital), which as a result of GCG had led to the interest rate on the funds or resources borrowed by the company smaller as the decrease in the company's risk. 3) Increase the value of the company's shares as well as to improvecorporate imageto the wider public in the long term. 4) Create the support of stakeholders in an enterprise environment that the existence and the various strategies and policies adopted by the company, because generally they have a guarantee that they receive the maximum benefit from the actions and operations of companies in creating wealth and prosperity.

Model of GCG of Anglo-Saxon. A CG model system followed by many English-speaking countries (English Speaking Countries) such as the United States, Britain, Australia and Canada. Generally, these countries embraced many Law Common Law system. The approach in this model emphasizes the separation of ownership between the owners (Principal) with shareholders. The orientation of this model is that many lead to an increase in the welfare of shareholders, where shareholders is considered an indirect owner, therefore the activity and any strategy that is run by the company boils down to maximizing shareholder value. A low concentration of ownership in Anglo-Saxon countries lead the shareholders do not have significant power in each company, the result is often greater management authority in decisionmaking.

GCG Model Continental (Continental European) a model of GCG system in force in the countries in continental Europe such as Germany and France that have a grounding in philosophy oriented stakeholders. These stakeholders include parties such as shareholders, customers, suppliers, distributors, bondholders and employees. In this model of shareholder ownership is highly concentrated in a small number of shareholders. Then the ownership becomes large so that the voting rights are held is also large. This resulted in the shareholders can use to control the company's ownership as well as to take a decision. Model of GCG according to Islamic Sharia Speaking about the notion of GCG in the Islamic Shariah would not be separated off from the difference between ShariahInterprise Enterprise Theory and Theory (SET) meaning is God at the center. SET balance the egoistic value (masculine) with altruistic values (feminine), the value of the material (masculine) with spiritual values (feminine), and so on. In the Islamic Shari'a, the equilibrium shape concretely realized in a form of worship, namely zakat. Zakat ("metaphor zakat") implicitly contains the value egoistikaltruistik, material-spiritual, and individujama'ah.

The consequence of this balance causes SET value not only care about the interests of individuals (in this case the shareholder), but also other parties. Therefore, the SET has a great concern. In SET, stakeholders include God, man, and nature. God is the highest party and become the only goal of human life. By placing God as supreme stakeholders, the tether that remained Shari'ah aims to "raise awareness to the deity" users is ensured. Consequences establishes God as the highest stakeholder is the use of the laws as a basis for the construction of shari'ah accounting. The point is that with this sunnatullah, accounting Shari'ah just built based on tataaturan or the laws of God. Stakeholder both of SET is human.

Here are divided into two groups, namely direct-and indirect-stakeholder 
stakeholders. Direct-stakeholders are parties who directly contribute to the company, either in the form of financial contributions and non-financial. Because they have contributed to the company, they are entitled to the welfare of the company. Meanwhile, what is meant by indirect-stakeholders are parties who did not contribute to the company (both financial and non-financial), but in Shari'ah they are the parties have the right to obtain the welfare of the company.

Last stakeholder group of SET is natural. Nature is party to contribute to the life and death of the company as part of God and man. Companies exist physically because it was established on the earth, using the energy spread in nature, produced using raw materials from nature, providing services to others by using the energy available in nature, and others. However, natural does not require the distribution of the welfare of the company in the form of money as would be desirable man. Being distribution of wealth in the form of the company's concern nature conservation, pollution prevention, and others.

\section{Islamic Financial Governance in Islamic Schools}

Concept of CG from the perspective of Islam is not much different from the conventional definition because it refers to a system in which companies are directed and controlled with a view to meet the objectives of the company to protect the interests and rights of all stakeholders. CG in the Islamic paradigm that presents differences in the characteristics and features as compared with the conventional system, in the special case of the theory of decision-making more extensive use of the premise of the epistemology of socio-scientific Islam that is based on the divine unity of God, Choudury and Hoque (2004) in Hasan (2009).

Financial governance according to Islamic Qur'an does not mention explicitly the concept of a financial institution. But the emphasis on the concept of the organization as a financial organization has been contained in the Qur'an. The basic concept kuamalah cooperation with various branches received considerable attention from the Koran. In a political system e.g. qaum common term to indicate the presence of a social group that interacts with the others. There is also a term ballad (country) to show their social structure, and also grandiose (government) to show the importance of a relationship arrangement between community members. Khalifah (leadership), is also a concern in the Qur'an. The concept of the organizational system, is also found in modern organizations.

Special on economic affairs, the Qur'an provides the basic rules, so that economic transactions not to violate the norms/ ethics. Further than that, the economic and financial transactions more oriented towards justice and prosperity of the people. The term suq (market) for example shows both how aspects of the market, should be the focus of an important business. Financial organization known as Amil. The agency not only served to charity affairs alone, but has a wider role in economic development. The division of booty, for example, indicate a mechanism which is equitable and fair distribution. Allah says in Surah An-Nisa verse

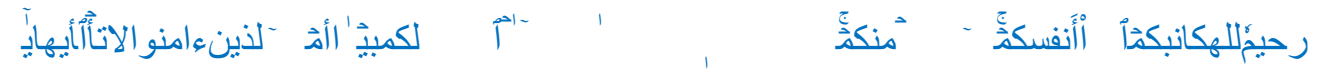


Meaning: $\mathrm{O}$ ye who believe, do not eat each other neighbor's property by way of vanity, except by way of commerce that goes with the same love-love between you. And do not kill yourselves; surely Allah is Merciful to you. [AnNisa: 29].

The above verse into a description to the institution with a clear organizational structure and is affiliated with the Islamic values in order to emphasize the importance of morals/ ethics. Referring to the characteristics of modern organizations such as; transparency and accountability, openness, egalitarianism, professionalism and accountability, as well as for serious concern. The Qur'an has long-standing rules and principles which form the basis for the establishment of a modern organization.

Accountability and transparency principles provide guidance that business organizations must demonstrate the principles of openness and free from manipulation. The concept of recording (in terms of modern economic accounting) for both the financial statements (profit and loss and changes in capital and other business administration) clearly stipulated in the Qur'an. As affirmed in Surat Al Baqarah verse 282.

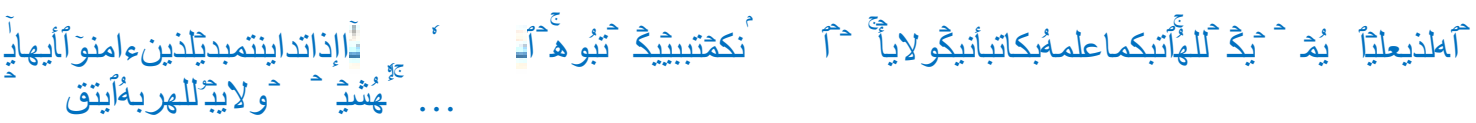

Meaning: O ye who believe, if you are not in cash amalahbermu for a specified time, you should write it. And let a writer among you write properly. And do not be reluctant writer to write as God taught him, meka let him write, and let those who owe it mengimlakkan (what would have written it), and let him fear Allah his Lord, and let it reduce its debt at all than ... (QS. Albaqoroh: 282)

In terms of some of these traits, it is clear that Islam emphasizes the importance of business settings correctly. To achieve prosperity and welfare, the way to organize themselves in a container to the demands. Business institution in Islam is not only function as collectors accumulate capital and profit, but also play a role in the formation of the economic system more equitable and free from despotic economic behavior. This explanation can be encountered in Surah Ali Imran verse 104.

$$
\text { (104)ئكُهمالمفلحُون ولتكنمنكمأمةيدعونإلتالخيرويأمرُونبالمعرُوفوينهونعنالمنكرو أول }
$$

Meaning: And be ye invent a bunch of people (agency business), which serves to invite to goodness, invite doing good and forbidding. They are the ones who are successful. (Qur'an, Ali Imran: 104).

Bring to virtue can mean towards the improvement of life and economic prosperity. do good and forbidding means also creating a climate and business systems Islami away from the system anarchist and exploitative.

Good governance is a set of responsibilities, practices, policies, and procedures 
undertaken by an institution to provide strategic direction, to make sure the goals are reachedand the resources are used responsibly and accountably. practice governance better support schools $d$ ith help them manage their resources so that they can provide quality education. World Bank (2017).

Principles of Islamic Finance Islamic School of Governance in Muqorobin (2011:4) states that good corporate governance in Islam must be based on the following principles:

a. Tawheed

Tawheed is the main foundation of the whole of Islam. Tawhid basis of the whole concept and all the activities of Muslims, both in economic, political, social or cultural. In the Qur'an mentioned that monotheism is the fundamental philosophy of Islamic Economics, as Allah says in the letter AzZumar verse 38:

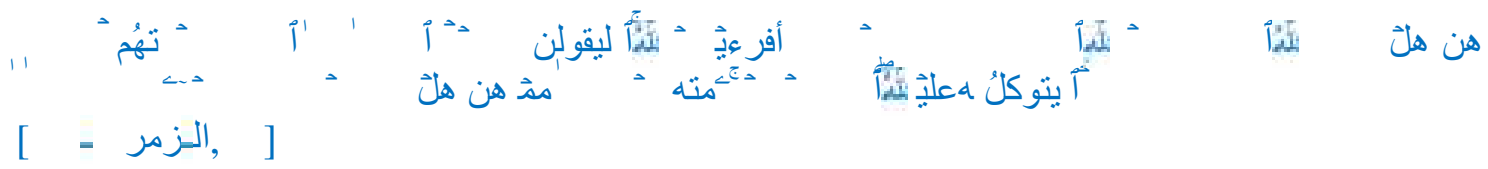

that is: and indeed if you ask them: "who created the heavens and the earth?", they would say, "Allah". Say: "Have you thought about what you call upon besides Allah, if Allah wanted to bring kemudharatan to me, whether it's your idols kemudharatan can eliminate it, or if, God gives grace to me, whether they can withstand his mercy ?. Say: "Allah is sufficient for me". to Him sole trust the people have surrendered. [Az-Zumar, 38]

The essence of monotheism also means surrender rounded to the divine will. Both involve worship and Muamalah. So all activity ysng do is in order to create the pattern of their lives according to God's will. If someone wants to do business, first he must know well the religious laws that govern trade so that he did not undertake the unlawful and harmful to society. inbermuamalah that must be considered is how to create an atmosphere and bermuamalah conditions are guided by the values of divinity.

b. Taqwa and the pleasure principle or principles of piety and pleasure of a primary principle the establishment of an Islamic institution in any form principles of piety to Allah and His good pleasure. Business governance in Islam, it must be established on the foundation on piety to Allah and His pleasure in Surah at-Tawbah:

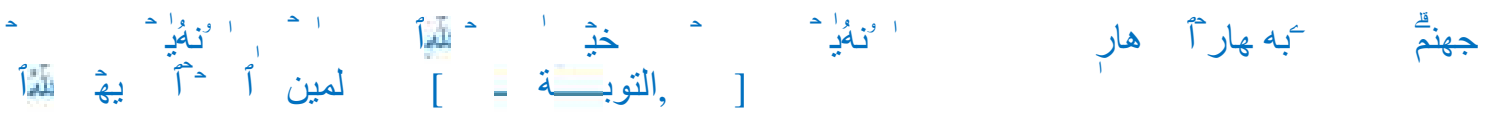

that is: So if the people who built the mosque on the foundation keridhaan- piety to Allah and (His) was good, or he who founded his building on the brink of collapsing, ? and it fell together with him into hell. And Allah does not give guidance to people who do wrong [At Tawbah, 109] 
In conducting a business let on consensual or voluntary. It is not justified that an act muamalah, such as trade, done by coercion or fraud. If this is the case, can undo these actions. The pleasure principle shows the sincerity and good faith of the parties.

c. Equilibrium (balance and fairness) tawazun or mizan (balance) and al-'is (justice) are two concepts of equilibrium in Islam. Tawazun more widely used in explaining physical phenomena, though it has social implications, which then often become the region al- 'is or justice as a manifestation of Tawheed especially in the context of civil society, including business and economic justice. Allah says in Surah ar-Rahman verses 7-9:

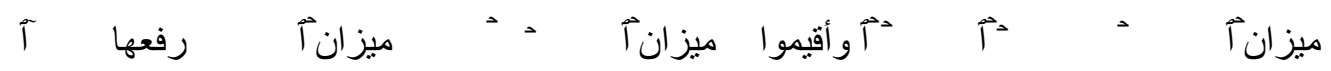

means: And Allah has raised the heavens and He put the balance (of justice). That you do not exceed the limits of the balance sheet. Establish weight with justice and do not reduce the balance of (Ar-Rahman, 7-9).

In the context of justice (social), the parties committed themselves required to apply correctly in the disclosure of the will and circumstances, fulfill the agreements they have made, and fulfill its obligations.

d. Generally, mashlahat interpreted as good (well-being) world and the hereafter. Experts of ushulfiqh define as anything that contains the benefits, goodness and avoid harm, damage and mufsadah. Imam al Ghazali concluded that mashlahat is an attempt to achieve and maintain five basic needs, namely: the maintenance of religion (hifdzuddin), maintenance of life (hifhzun-nafs), the maintenance of reasonable (hifhzul-'aql), maintenance of offspring (hifhzun-nasl), the maintenance property (hifhzul-maal). Principles of CG in Islam above using values derived from the Qur'an, hadith, ijma and qiyas scholars' so-called Islamic Governance implementation. Muqorobin (2011:4)

e. Accuracy is also a principle of transparency is important in the implementation of Islamic CG. Accurate information can be obtained if the existing system in the company can ensure the realization of justice and fairness to all parties. This condition can be achieved if any company running a business ethics Islami and supported with good accounting system in a fair and transparent disclosure of all business activities.

f. Accountability Accountability is not only limited to financial reporting is honest and fair, but more mengedapankan essence of human life is a human form of accountability to God as the One owner of the entire universe. Islamic concept which fundametal believes that nature and all its contents fully belong to God and man entrusted to manage as well as possible for the benefit of the people.

g. Accountability (responsibility) the company's financial accountability also needs to be delivered in the form of an honest and fair disclosure on the company's financial 
condition. So that shareholders and stakeholders can make informed decisions. Proper financial reporting and accurate, it will also result in accuracy in the payment of zakat. Because of every Muslim gains in its business activities, at least 2.5 (two point five) percent of the rights of the needy. Problemzakat to be important in the Islamic perspective because it is the hallmark of the implementation of GCG. GCG is not only aimed at the prosperity of management and shareholders, but also the surrounding community, especially the needy and the poor.

h. IndependenceIndependence is about consistency or attitude istiqomah that clung to the truth even in the face of risk, Allah says:

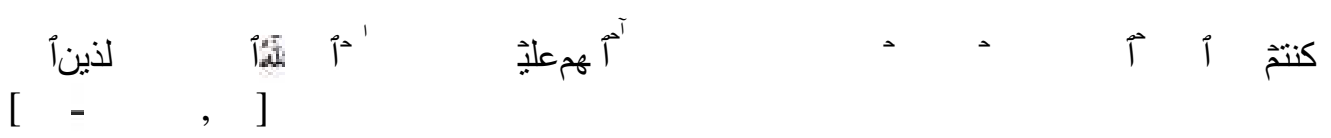

That: Verily those who say: "our Lord is Allah" and then they were affirming their stance, then the angels will descend upon them, saying: "do not be afraid and do not feel sad; and announce them with jannah that God had promised to you" [ Fussilat: 30]

Independent is a wise human characters (ulul al-chapters) in the Qur'an is mentioned sixteen times, that between his character is "Those who are able to absorb information (heard) and a decision (to follow) the the best (according to de ngan conscience without pressure of any party) ".

i. Justice recording principle of honest, accurate and fair also been arranged in the Qur'an (2: 282-283) and the Qur'an (21: 47) also stressed that the records of financial transactions should be done properly and correctly. Those responsible for the registration should have their fair and just. Again, this indicates Islam requires the convening of its business fairly and honestly for all parties. The main advantages coporate governance in Islam is the main orientation of the company's management is God's responsibility as owner of nature and its contents. The application of Islamic ethics in business that ensures a square deal, fair to all parties has also become the main reference of GCG. GCG is run not only as a form of management to the owners of capital, but rather on the basic needs of every Muslim to enforce Sharia Law as a whole and perfect. With the basic belief in God then GCG will motivate business transactions honest, fair and accountable.

Benefits of Islamic Governance of Financial Islamic School of benefits to be gained from the Islamic Governance on finance Islamic schools include: 1) A system that is more Islamic, democratic and responsive than pengelolahan finance

Islamic schools, including resource utilization more efficient 2) Participation greater of all stakeholders (teachers, students, parents and school management) in the development of policies, regulations, plans, and appropriate school conduct codes Islamic values. 3) Greater transparency in all school activities, including an increase in the flow of information among school stakeholders about the plans, finances, rules and regulations, and programs openly. 4) Strengthening accountability among stakeholders to improve 
The financial pengelolahan Islamic school. 5) Coordination between the various levels of formal government (for example, the Department of Education, Resource Center, or other educational institution), 6) a more open communication among stakeholders about howto manage schools.

\section{Education Financing}

Definitions Education Financing Education Financing costs in the concept of Language Britain used to use the term cost, financial, expenditure. Cost by accountants in Usry and Hammer (1991:23) is as synonymous with the cost expense that is used to menhukur expenditure (outflow) of goods or jasayang juxtaposed with measuring income revenue.

... the Decrease in net assets as a result of the use of economic services in the reaction of revenves of the imposition of taxes by government units, Expense is measured by the amount of the Decrease in assets od Increase in liabilities related to the production and delivery of goods and the rendering of services. Expense in its broadest sense include all expired roomates costs are deductible from revenues. (Usry and Hammer, 1991:23)

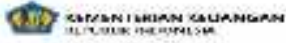

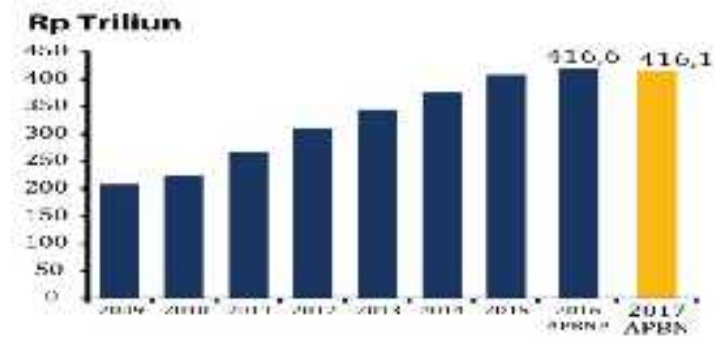

ANGGARAN PENDIDIKAN

\author{
Anggaran Pendidikan 2017 \\ tetan dijage $20 \%$ \\ diari APISN, derigari folku. \\ meningkatkan \\ akses clan \\ kualitas layanan \\ pendidikan.
}

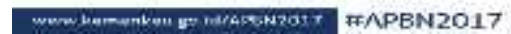

\section{SourceEducation budget}

Figure 2.1Education budget

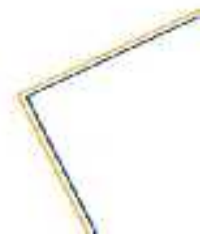

Scarce resources and limited need to be allocated and distributed in accordance with the needs of education. In the economic concept of resources used to produce a product (tangible and intangible) was very limited or scarce (scarity) and the need for efficiency.

Budgeting is an activity or process of preparing the budget. Budget as operational plans in terms of money into guidelines for the implementation of activities within a certain time. Basically the budget is negotiating or bargaining between the top leadership with the leadership in determining thebelowmagnitudecost of a budgetary allocation, (Fattah, 2000:47). Thus, between allocation and budgeting is a package that is inherent in the concept and its application. 


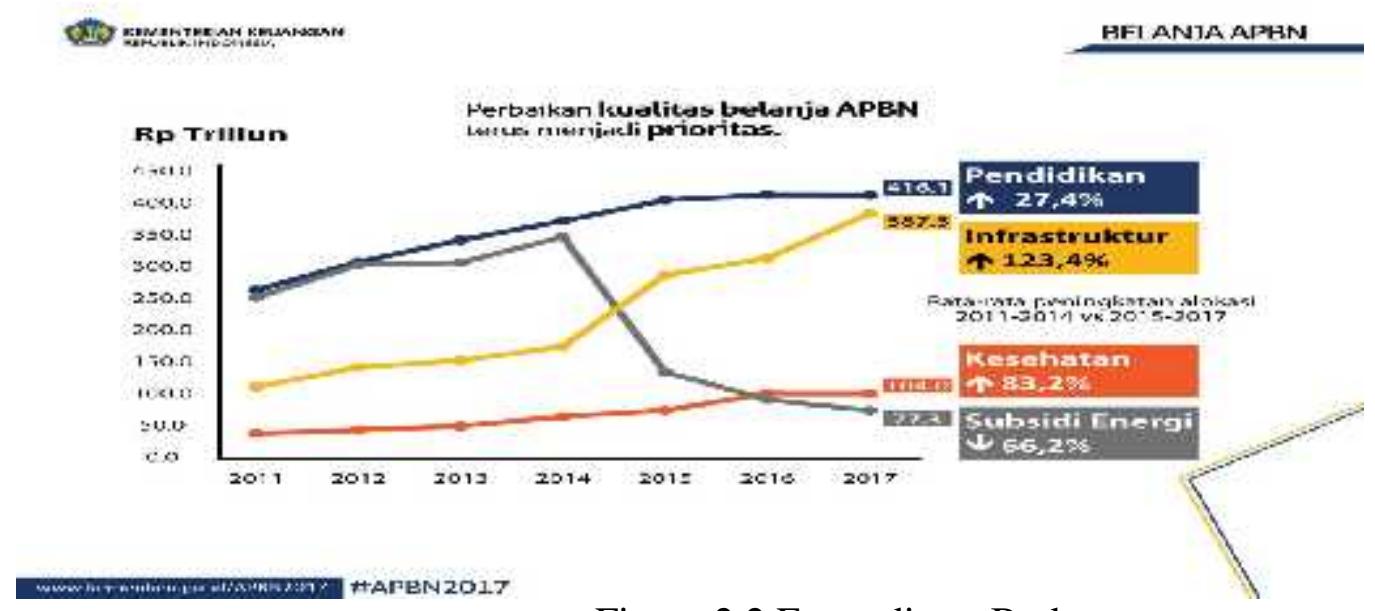

Figure 2.2 Expenditure Budget

Judging from its sources, the cost of education at the macro (national) attributable to: 1) the state income tax sector. 2) Revenue from non-tax sectors, for example on the use of natural resources andnational production of other commonly categorized into "gas" and "non-oil". 3) Gains from exports of goods and services. 4) The efforts of other countries, including from the divestment of shares in state enterprises(SOEs). 5) assistance in the form of grants and loans from abroad either from international financial institutions (World Bank, ADB, IMF, IDB, JICA) and the government, both through multilateral and bilateral cooperation.

School Operational Assistance Now that the government has sought an increase in education funding to fund School Operational Assistance (BOS). BOS is a government program that is basically for the provision of funding the operating costs of non personnel for basic education units as the executor of compulsory education. According to Regulation 48 of 2008 on Education Funding, non-personnel Cost is the cost of materials or educational equipment consumables and indirect costs such as power, water, telecommunication services, maintenance of facilities and infrastructure, overtime, transportation, consumption, taxes etc. However, there are several types of investment funding and personnel are allowed to be financed by the BOS.

BOS program generally aims to alleviate the burden on society in order to finance education compulsory 9 years of quality. While specifically program BOS fund aims to: 1) Freeing levy for all students SD/ SDLB country and SMP/ SMPLB/ SMTP (Open) country towards the operating costs of the school, except for the international school (RSBI) and the International Standard School (SBI ). Contributions/ levies for schools RSBI and SBI should still consider the function of education as non-profit activities, so that contributions/ levies should not be excessive; 2) Freeing levies entire poor students of all charges in any form, either in public and private schools; 3) Relieve the burden of school operating costs for students in private schools.

Budgeting by Matin (2014), budgeting is a decision-making process to regulate the use of resources in the future. Budgets are often interpreted as a plan, but in the field 
of financial management in educational institutions is often referred to RAPBM. There are two parts to the budget, the estimates of revenue and expenditure. Estimates and revenue presentation should be held so that it can be realized. The cost of education is generally defined as spending some money to pay for education.

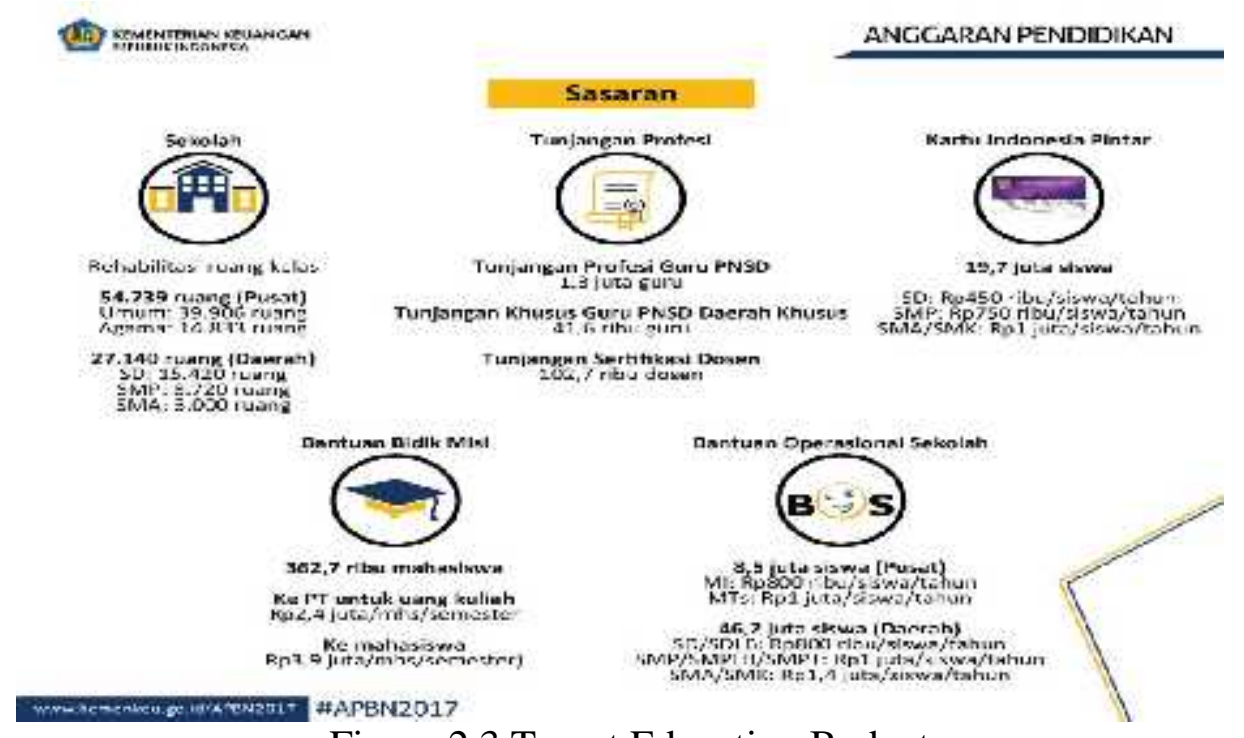

Figure 2.3 Target Education Budget

Investment in education is necessary to respond to the economic needs of workers by type of education. Investment is the sacrifice of a certain value at this time to obtain a value (returns) the future with more hope thancertainlygreater than the current value. School investment costs include the cost of providing infrastructure and human resource development costs. Meanwhile, personnel costs include all kinds of financing to be incurred by school students, including tuition fees and the cost of lab work, in order to follow a regular and ongoing learning.

The operational costs of schools according to Government Regulation No. 32 Year 2013 Article 62 covers the cost of investment, operating costs and personnel costs. The investment costs include the provision of infrastructure, human resource development, and permanent capital. While operating costs include three components, namely: (1) salaries of teachers and education personnel as well as all the benefits attached to the salary; and (2) the substance or educational equipment consumables (boardmarker / chalk, eraser, ink, typing paper and so on); (3) and indirect operational costs namely education facilities and infrastructure maintenance costs, overtime, transportation, water, services, electric power, telecommunications, insurance and so on. Admission fees HM Levin schooling in Armida stated that school refer to the financial revenue receipts of school for supporting Reviews their operations. Such revenues can be derived from taxation, tuition charges, and student fees as well as from contributions and income from the provisions of goods and services.

Relation to the budget is the need to apply the principle of a balanced budget, meaning the plan of income and expenditure must be balanced strived not occur minus 
the revenue budget. With a balanced budget the school life will be effective and efficient in terms of finance, so that the centralization of financial management needs to focus on school bursar, in order to facilitate financial accountability.

The authors concluded that the budget is a plan that shows the amount of money they had to finance the activities of the educational process in order to achieve educational goals. The Development Budget Plan School (Budgets) The development process RAPBS generally take step approach with the following procedures:

1) At the level of working groups established madrasas consisting aides headmaster has the task, among others, to identify needs for future costs classified and performed calculations as needed.

2) At the level of cooperation with the school committee with working groups have been formed should be a board meeting and a meeting of members in developing activities that must be carried out in connection with the development RAPBM.

3) Orientation and legality after Budgets discussed with the school committee subsequently disseminated to various parties. the promotion phase and the legality of the working group to consult and report on the regulatory side, and make proposals to the Office of Religious Affairs RAPBS to receive consideration and ratification.

Financial Accountability Schools All schools financial expenses from any source should be accounted for, it is a form of transparency in financial management. However, the principles of transparency and honesty in such liability shall remain upheld.In connection with the financial management, to be considered by the treasurer by Suryana (2008) are: 1) At the end of each fiscal year, the treasurer must make financial reports tothe school committee to be matched with RAPBS. 2) The financial statements must be accompanied by evidence of existing expenditure. 3) receipt or proof of purchase or receipt and evidence of other expenses. 4) The balance sheet must also be shown to be examined by a teamaccountabilityof financialof the school committee.

\section{Cost of Education Cost Analysis in education}

Cost analysis includes direct costs and indirect costs. This is in accordance with the opinion of R. John, Edgar L. Morphet, and Ken Alexander (1983:45). According to Cohn (1979:62) in Yusof (2013:6) cost of education can be categorized as follows:

a. Direct costs, ie costs incurred directly to finance the implementation of teaching, research, and community service, such as teacher salaries, employee non-educative, textbooks, and other supplies materials. This affects the educational outcomes of valuesacrifice for the implementation of these activities. b. Indirect costs (indirect costs), which includes the loss of income because learners were studying. It could also be the lost profits (earnings forgone) in the form of lost opportunity costs (opportunity cost) are sacrificed by students while studying.

In the concept of education funding at least three statements related despair therein. As stated by Thomas John (1985:20) in Akdom (2015), that is, how the money raised to finance educational institutions, from which source, and to what is spent and who is spending. This is a business management or administration of educational 
institutions. Later, he describes three important things, namely economics related to the allocation and distribution of financing. However, the third relates to management which include the functions of the components of planning, implementation, and evaluation. Thus, there is a difference of emphasis between the economics of education and education funding. Financing education is an activity with respect to proceeds (revenues) received and how the money will be used to fund all the programs that have been established. Income or source of funds received by the school education obtained from the state budget, budget, and society or parents. Bowen (1981:18) in Akdom (2015:23) in more detail to explain that:

Revenues are derived from Several sources: federal, state, and local appropriation, tuitions, gifts and grants from private individuals and corporations, endowments, and sales of goods and service. The revenue theory of educational costs is subject to an important qualification.

As for how your use of these funds, according to John, Morphet, and Alexander (1983), every school should establish plans to prioritize the funding of education in a comprehensive manner. Comprehensive planning of a school funding program involves making critical decisions in key areas include; educational programs should be financed, the tax system which is used to finance the program, and the system of allocation of state funds to regions or areas of schooling. 
In the organization of the school, the financing of using the budget as stipulated in the budgets. Own budget by Mardiasmo (2002) provides an action plan that is represented in the form of revenue and expenditure plans in monetary units. In its simplest form, the budget is a document that describes the financial condition of an organization which includes information on revenues, expenditures, and activity. Public sector budgeting associated with the process of determining the amount of the allocation of funds for each program and activity in monetary units. The budget is prepared with a cost of detailed plans. More specifically it can be said that the budget is a plan arranged organized to receive and disburse funds for a certain period. While the education budget is the budget allocation to the education function is budgeted through the state ministries/ agencies and budget allocations for education through transfers to the regions, including the salaries of educators, but does not include service education budget, to finance the provision of education is the responsibility of the government. In accordance with the decision of the Constitutional Court Number 13/ PUU-VI I in 2008, the government must provide the education budget at least 20 percent of state and local budgets to meet the needs of national education.

In the context of education financing in Indonesia, according to team results from the Asian Development Bank (1998:30) the source of financing came from agencies or departments that play an important role, namely the Ministry of Education, Ministry of Interior, Ministry of Religious Affairs, Ministry of Finance and Bappenas. Education financing are grouped into two, namely the regular budget, as contained in the DIK and development budget, as contained in the DIP. Although the regular budget concerning the salaries of teachers and other educational personal. All budgets are organized in the State Budget (APBN).

The cost of education in Indonesia is one of satau perceived problems still crucial although not fully complete financing problems directly influence the quality of education, but is closely related to the smooth financing of teaching in schools, including the provision of infrastructure and learning resources. How many schools can not conduct learning activities optimally only because of financial problems both for hire teachers and provision of facilities and infrastructure for learning. In this regard, although the demands for reform requires cheap and quality education, quality education but always require a small cost.

Bobbit (1992) in Fatah (2009) found school independently and fully manage budgets efficiently. As an example of effectiveness and efficiency in providing education conducted Jembrana- Bali District Government. The district since 2001 is able to provide 12-year free education for the indigenous people of the area. Educational equity, effective education management, and increased participation.

Community is the basis of the education program launched in Jembrana.

Under conditions of very limited funds and schools are faced with diverse needs, then the school should be able to make a decision by referring to the quality improvement. When the school has plans to make improvements such as fencing school facilities or planned procurement of laboratory equipment, the school needs to consider the priority which is assumed to have a dominant influenceon the quality improvement. If the consideration and on the basis of consultation and consensus with stakeholders, 
CENDEKIA, Vol. 12, No. 1, April 2018

p ISSN: 1978 2098; e ISSN: 2407 8557

Http://cendekia.pusatbahasa.or.id; Email: cendekiaoslo@gmail.com

Center of Language and Culture Studies, Surakarta, Indonesia

Hamid, Munir Ahmad. 2018. Islamic Governance in Islamic School Finance.

Cendekia, (2018), 12(1): 1 22. DOI: 10.30957/cendekia.v12i.433.

procurement props more labs have a strong impact, it is the most efficient decision held props laboratory.

The efficiency of education funding is determined by the accuracy in the utilization of the education budget by giving priority to the educational input factors that can stimulate the learning achievement of learners. Plan Budget School (Budgets) is a draft of the financing of education at schools in order to manage and allocate education funding source is already calculated the number and magnitude, either a routine budget assistance from the Government in the form of operational funds or other funds came from public donations or parents of students.

The steps of the preparation of Budgets by Suryana (2008) is as barikut: 1) Inventory plan that will be implemented. 2) Develop a plan based on priority implementation. 3) Determine the work program and the details of the program. 4) Establish the need for the implementation of the program details. 5) Calculate the needed funds. 6) Determine the source of funds to finance the plan. The plan, after discussion with the board and the school committee, then the next set as school income and expenditure budgets after examination by the Department of Education at district/ city level. At every budget drawn up should be clarified whether the budget plan that will be implemented is new or the continuation of the activities that have been implemented in the previous period by calling the previous funding sources. In every budget prepared for the activities in the school environment, according to Suryana (2008) must contain at least six things or information as follows: 1) Information action plan: objective, description of planned activities, responsible,plana newor advanced. 2) Description of program activities, work programs, the details of the program. 3) The information needs: goods/ services required, the volume of needs. 4) Data needs unit price, the amount needed for the entire volumeneeds. 5) Total budget: the budget amount for each program details, program,plan activities, and the total budget for all planned activities. 6) Source of funds: total funding sources, each source of funds to supportthe financing of the program.

Implementation of financial principles above on education, especially in the school environment and harmony between education in the family, in schools and in society, for sources of school funding, the school was not only obtain the budget and facilities from the government or donors still but from the source of the three components.

For that school is actually also necessary to set up organizations of parents whose implementation is done by forming a school committee. The committee consists of representatives of the parents/ guardians of students, community leaders, managers, government representatives and representatives of scientists/ scholars outside of school and may also enter the world of business and industry (the game 44 of 2003).

The joint school committee or school assemblies at the beginning of each budget year should jointly formulate Revenue and Expenditure Budget Plan School (Budgets) as a reference for school administrators in implementing the financial management of the school is good. In the implementation of activities, the amount realized is not the same could happen with the budget plan, can be less or more than the amount that had been budgeted. This can happen for several reasons: The presence of the efficiency or 
inefficiency of spending, saving or waste occurrence, implementation of activities that are not in accordance with the predefined, existence of unanticipated price changes. Lack of proper budgeting (Suryana, 2008) further, the analysis covers education costs in the cost-effectiveness, benefit cost, cost-utility, and costfeasibility.

Furthermore, detailed cost analysis of each are described as follows: 1) analysis of cost-effectiveness. A job is called effective if the work is done properly and achieve the desired objectives. The cost of education is used effectively means the cost of it is directed only to achieve educational goals that turned after completion of work educating the originally planned objectives are actually achieved; 2) The cost-benefit analyzes. This analysis connects the major cost incurred by the revenue after undergoing education or training; 3) The cost benefit analysis is an analysis that attempts to compare costs used by an alternative to the estimated benefit or value outcomenya; and 4) Analysis of charge kefisibilitas. This analysis can not be measured quantitatively as the previous analysis, this analysis only see whether the costs used by the alternative is enough or not, when linked with the available funds. When the alternative costs exceeded the funds and other educational resources, the plan can not be implemented, or the alternatives are not feasible.

\section{CONCLUSION}

From the results of the discussion and findings obtained, the conclusion of this study that the principles of CG in general is part of Islamic Shari'a values, so that in its development required a combination of these principles into principles of Islamic governance permanent. From some schools, madrassas or Islamic organizations under the auspices of large Islamic organizations that there are still many violations and irregularities in the practice of Islamic Governance, especially on good financial management more Islamic. In essence Principles of Islamic governance is a derivative of Islamic sharia values sourced from kalamullah and His apostles so that in an effort to improve efficiency, competitiveness and innovation development must be in accordance with Islamic Shari'a.

\section{REFERENCES}

Antonio, Muhammad Syafi'i. 1997. AsuransidalamPerspektif Islam. Dalam Mustafa Kamal (Ed.), Wawasan Islam danEkonomi: SebuahBungaRampai (hlm. 253263). Jakarta: LembagaPenerbitFakultasEkonomiUniversitas Indonesia.

Effendi, Muh. Arief. 2016. The Power of Good Corporate Governance: TeoridanImplementasi. Jakarta: SalembaEmpat.

2009. The Power of Good Corporate Governance: TeoridanImplementasi. Jakarta: SalembaEmpat.

Hafeez, Malik M. (2016), An analysis of corporate Governance in Islamic and Western Perspectives. International Journal of Business, Economics and Law, 2(3):221234.

Hoque, Mohammad Ziaul, 2006, Corporate governance in Islamic perspective?. International journal of business in society, 6(2):116-128. 
http://www.kompasiana.com/ikayulip/perkembangan-bank-syariah-diindonesia_572ac4d3f1927349059f6b6f (diakses 29 juni 2017). http://www.republika.co.id/berita/ekonomi/syariah-ekonomi/17/01/18/ojy976382-

bisnis-bank-syariah-2017-berpeluang-terus-melonjak-ini-alasannya (diakses 29 juni 2017).

Ishomuddin, (2014) Some Islamic Higher Education Strategies to Tackle and Take Opportunities in the Era of Globalization.Journal of Education and Practice, 5(12): 876-889.

Jumansyah, 2013, Analisis Penerapan Good Governance Business Syariah dan Pencapaian. Surabaya: PT Eka Ilmu.

MaqashidShariah Bank Syariah di Indonesia.Jurnal al-azhar indonesia seri pranata sosial, 2(1): 46-58.

Muqorobin, Masyudi. 2011. Fikih Tata KelolaOrganisasiLaba: SebuahPengantar. Disampaikanpada Seminar Nasional Tata KeloladanRapatKerjatanggal 25-27 Maret 2011, Universitas MuhammadiyahPurwekerto.

Othman, Radiah (2015), Conceptualizing the duties and roles of auditors in Islamic financial institutions What makes them different? Humanomics, 31(2): 201-213.

Razimi, Mohammed Shahril (2016), A Conceptual Study on Islamic Corporate Governance Model in Curtailing Bank's Fraud.International Journal of Economics, Finance and Management Sciences, 4(6): 346-362.

Sutedi, Adrian. 2011. Good Corporate Governance. Jakarta: SinarGrafika.

Soraya, Reskietc, 2016. Good Corporate Governance dalam Perspektif Islam dan Penerapannya pada Bisnis Syariah di Indonesia. Proceeding.

Sciabolazza, Valerio Leone, (2014). A consensus-based corporate governance paradigm for Islamic banks.Qualitative Research in Financial Markets, 6(1): 93-108, doi: 10.1108

Thalib, Muhammad, 2012, Al Qur'anul Karim TarjamahTafsiriyah, CV. Qolam Mas 